ГАЛУЗЕВИЙ АСПЕКТ РОЗВИТКУ НАЦІОНАЛЬНОГО ГОСПОДАРСТВА

UDC 519.866:658.264

DOI: $10.25140 / 2411-5215-2018-4(16)-131-139$

Nadiia Yushchenko, Yaroslav Petrakov, Kateryna Hnedina

\title{
METHODICAL FOUNDATIONS FOR MODELING THE TIMING OF MODERNIZATION OF UKRAINE'S ENERGY FACILITIES IN CONDITIONS OF LIMITED LABOR, MATERIAL AND FINANCIAL RESOURCES
}

Надія Ющенко, Ярослав Петраков, Катерина Гнедіна

МЕТОДИЧНІ ЗАСАДИ МОДЕЛЮВАННЯ ТЕРМІНІВ МОДЕРНІЗАЦЇ̈
ЕНЕРГЕТИЧНИХ ОБ'СКТІВ УКРАЇНИ В УМОВАХ ОБМЕЖЕНОСТІ
ТРУДОВИХ, МАТЕРІАЛЬНИХ І ФІНАНСОВИХ РЕСУРСІВ

Надежда Ющенко, Ярослав Петраков, Екатерина Гнедина

\section{МЕТОДИЧЕСКИЕ ОСНОВЫ МОДЕЛИРОВАНИЯ СРОКОВ МОДЕРНИЗАЦИИ ОБЪЕКТОВ ЭНЕРГЕТИКИ УКРАИНЫ В УСЛОВИЯХ ОГРАНИЧЕННОСТИ ТРУДОВЫХ, МАТЕРИАЛЬНЫХ И ФИНАНСОВЫХ РЕСУРСОВ}

The article devoted an adaptation of economical and mathematical models, existing in the theory of network planning and management for determination of time reserves, with the help of which both labour and material, as well as financial resources can be efficiently and rationally allocated within the set of interrelated works. The proposed approach can be used in the process of development of measures to increase the energy efficiency rate, which will involve intensification of innovation activities, more complete implementation of social and economic potential of business entities and local communities.

Keywords: energy efficiency; network model; methods and models of project management; time reserve; heat supply.

Fig.: 1. Table: 3. References: 15.

Стаття присвячена адаптації існуючих у теорії планування й управління мережами економіко-математичних моделей визначення резервів часу, щь дозволяють рачіонально та збалансовано розподіляти ресурси в межах комплексу взаємопов'язаних робіт. Пропонований підхід може застосовуватись у проиесі розробки заходів, спрямованих на підвищення рівня енергоефективності, щзо передбачають активізачію інновачійних прочесів, більи повну реалізацію соиіального й економічного потенціалу суб 'єктів господарської діяльності та органів місиевого самоврядування.

Ключові слова: енергоефективність; мережева модель; методи і моделі управління проектами; резерв часу; теплопостачання.

Рис.: 1. Табл.: 3. Бібл.: 15.

Статья посвящена адаптащии существующих в теории планирования и управления сетями экономикоматематических моделей определения резервов времени, что позволяют рачионально и сбалансировано распределять ресурсы в пределах комплекса взаимосвязанных работ. Предлагаемый подход может применяться в прочессе разработки мероприятий, направленных на повышение уровня энергоэффективности, предусматривающих активизачию инновационных прочессов, более полную реализацию соииального и экономического потенциала субъектов хозяйственной деятельности и органов местного самоуправления.

Ключевые слова: энергоэффективность; сетевая модель; методы и модели управления проектами; резерв времени; теплоснабжение.

Рис.: 1. Табл.: 3. Библ.: 15.

JEL Classification: C13, C41, Q48, R15

Relevance of the research topic. Implementation of the plan of energy efficiency operations, stimulation of energy consumption reduces, creation of transparent and competitive environment to attract investments into the industry, as well as the growth in energy efficiency of state and municipal property objects is one of the chief tasks of the Cabinet of Ministers of Ukraine defined by the Program [1]. However, the current procedure of heating energy pricing by respective authorities is based on the „out-of-cost" principle, which significantly reduces the possibility of real increase in the efficiency of central heating system [2]. The operational practice of calculation of heating tariffs at the stage of its release into the network results in the lack of financial incentives for the reconstruction of heating system, thus determining low rates of its restoration. Ukrainians are forced to pay for the heating energy, $45 \%$ of which they do not actually receive because of its loss during the transportation. In fact, nobody takes care of the quality (temperature) of the heat carrier received by consumers, as everything has been already paid.

() Ющенко Н. Л., Петраков Я. В., Гнедіна К. В., 2018 
ГАЛУЗЕВИЙ АСПЕКТ РОЗВИТКУ НАЦІОНАЛЬНОГО ГОСПОДАРСТВА

Problem statement. Adaptation of economical and mathematical models and critical path method (CPM), Program Evaluation and Review Technique (PERT) and making decisions on stochastic GERT-networks (Graphical Evaluation and Review Technique), which are existing in the theory of network planning and management, will increase effectiveness of scheduling the implementation of works that can be substantial by their volumes, cost and time, the project management as for replacement and/or upgrade of generative points and networks for the transportation of steam, hot water and conditioned air. This foresees a large amount of interrelated works that must be executed in strict technological sequence, requiring proper timing and control in order to achieve a certain goal.

Analysis of the last researches and publications. Scientific works by P. Lazanovskyi [3], Ya. Sybal, I. Ivanytskyi, Z. Kadyuk [4], V. Sokhan [5], O. Timinskyi [6] and other researchers are devoted to the application of a method of network planning and management in various types of economic activities.

Open parts of a shared problem. Despite the considerable number of scientific works and growing attention to this problem, the task of modeling on the basis of the theory of graphs and analysis of networks in the system of technical improvement and technological upgrade of heat-power engineering objects, in order to increase the energy efficiency of energy consuming equipment, to reduce the rate of energy losses in supply networks, to minify specific costs per one unit of output (generated energy unit) and to raise the efficiency of final energy consumption is significant on a practical level and requires amplification.

Problem definition. The purpose of the article is an adaptation of economical and mathematical models, existing in the theory of network planning and management for determination of time reserves, with the help of which both labour and material, as well as financial resources can be efficiently and rationally allocated within the set of interrelated works.

Statement of the main material. When applying network methods, the minimum duration of a project is determined by the sequence of works, which form the longest (a so-called critical) path through the network, and those works creating the critical path are called critical works, so any increase in their duration or delay in their execution cause an increase in the time of project implementation as a whole. Availability of time reserves will give the users some freedom in allocating particular resources.

In today's realities of rapid development of new information and communication technologies, which form the informational society and, in particular, the informational economy, with modeling as their intellectual core [7], during the planning of projects with the use of computer technologies, together with the network models and methods, the most relevant way is the statement of a problem in the form of a "node-work" model. The difference of a „nodework" model from a ,node-event" model is that the notion of an event is not introduced: various works within the network are displayed by nodes, while arcs only reflect the relation of top priority, that is the time is spent in knots, but not in arcs. Construction of the network is not a complicated task due to the introduction of only two conditional works, both having a zero duration: the first of them means a „,beginning”, preceding all other works, and the second of them means an ,ending”, following the completion of all works. Using the mathematical model there is no need to use symbols with double sub-indices, as in the case of designating any work with an arc, since all the works are uniquely linked to one particular node, one index will be enough [8, p. 309-313].

Four indicators of the time reserve for each of the works (Table 3) are calculated using the following relationships.

$$
T F_{i}=L S_{i}-E S_{i} \text { or } T F_{i}=L F_{i}-E F_{i}-\text { total time reserve. Work with a zero time reserve }
$$
is on a critical path; 
ГАЛУЗЕВИЙ АСПЕКТ РОЗВИТКУ НАЦІОНАЛЬНОГО ГОСПОДАРСТВА

$$
F F_{i}=\min _{X \in S_{i}}\left[E S_{X}-E F_{i}\right]-\text { free time reserve - measures available time that does not af- }
$$

fect the performance of subsequent work;

$$
I F_{i}=\max _{X \in S_{i}}\left\{\begin{array}{l}
0, \\
\min E S_{X}-\left[\max _{Z \in P_{i}} L F_{Z}+d_{i}\right]-\text { an independent time reserve is an indicator }
\end{array}\right.
$$

of the possible degree of disruption of communication between the project's work and the available time in the event that the worst possible circumstances occur during the execution of the previous work;

$$
S F_{i}=L F_{i}-\max _{Z \in P_{i}}\left[L F_{Z}+d_{i}\right]-\text { guaranteed time reserve }- \text { allows only the delay of sub- }
$$
sequent work, but not of the entire project.

Here $d_{i}$ - the time spent on doing the $\mathrm{i}$-th work, $i=\overline{1 ; n}$;

$P_{i}=\{a \mid a<<i\}-$ a lot of works that are performed immediately before work $\mathrm{i}$ (the previous set of works); the symbol , $<<"$ denotes the ratio of direct precedence (foreground), for example, $\mathrm{i}<<\mathrm{j}$ - work $\mathrm{i}$ is performed immediately before work $\mathrm{j}$, or work $\mathrm{j}$ is performed immediately after i-th work;

$S_{i}=\{a \mid i<<a\}-$ a lot of work that must be done immediately after work i (the subsequent set of works);

$E S_{i}$ - the earliest possible start date for the i-th work;

$E F_{i}$ - the earliest possible completion date for the i-th work;

$L S_{i}$ - the latest allowed start date for the i-th work;

$L F_{i}$ - the latest allowed date for the end of the i-th work;

$\mathrm{T}$ - planned completion date of the project; is necessary $T \geq E F_{\text {ending }}$, is adopted $T=E F_{\text {ending }}$

$E S_{\text {beginning }}=E F_{\text {beginning }}=0$ - for the conditional work „Beginning of the project”,

$E S_{i}=\max _{X \in P_{i}}\left[E F_{X}\right]$ and $E F_{i}=E S_{i}+d_{i}-$ for all subsequent works, and calculations must be performed from earlier to later works in such a way that each work is considered before its appearance in the immediately preceding set of another work;

$L F_{\text {ending }}=L S_{\text {ending }}=T$ - for conditional work „Ending of the project”,

$L F_{i}=\min _{X \in S_{i}}\left[L S_{X}\right]$ and $L S_{i}=L F_{i}-d_{i}$ - for all other works, and, as in the previous case, the movement is carried out in the opposite direction, each work is considered before its appearance in the immediately following set of other work.

Implementation of economical and mathematical models of time reserves, systematized in [9], can be carried out through the use of software products (Table 1) - comparative characteristic of their functionality has been completed in [10]. Calculations (Table 3) in accordance with the initial data from Table 2, regarding the replacement of heating network area, has been performed in MS Excel. 
The most common project management systems and tasks

\begin{tabular}{|c|c|c|c|}
\hline Name & Developer & Official site & \begin{tabular}{|c|} 
General characteristics \\
\end{tabular} \\
\hline $\begin{array}{l}\text { Microsoft } \\
\text { Project }\end{array}$ & $\begin{array}{l}\text { Microsoft Corp. } \\
\text { (USA) }\end{array}$ & $\begin{array}{l}\text { http://www.m } \\
\text { icrosoft.com/p } \\
\text { roject }\end{array}$ & $\begin{array}{l}\text { It is the most widely used project management system in } \\
\text { the world, recommended for both entry level users and } \\
\text { professionals. In many Western companies, Microsoft } \\
\text { Project is seen as a standard component of Microsoft Of- } \\
\text { fice, and even ordinary employees are able to use it for } \\
\text { work planning. Traditionally understandable interface of } \\
\text { Microsoft products and ease of use are supported by broad } \\
\text { properties of building and calculating network graphs, } \\
\text { Gantt charts, time and resource planning tools, other tools }\end{array}$ \\
\hline Open Plan & $\begin{array}{l}\text { Welcom Corp. } \\
\text { (USA); distributor } \\
\text { in Ukraine - } \\
\text { LANIT company }\end{array}$ & $\begin{array}{c}\text { http://www.pr } \\
\text { ojectman- } \\
\text { agement.ru }\end{array}$ & $\begin{array}{l}\text { It is a system for planning and monitoring large projects } \\
\text { and programs. The main differences of the system are } \\
\text { powerful resources of resource and cost planning, effec- } \\
\text { tive organization of multi-user work and the possibility of } \\
\text { creating an open, scaled solution for the entire enterprise. } \\
\text { Open Plan comes in two variants - Professional and Desk- } \\
\text { top, - each of which corresponds to different needs of ex- } \\
\text { ecutors, managers and other project participants. There is } \\
\text { a localized version of the product }\end{array}$ \\
\hline $\begin{array}{l}\text { Primavera } \\
\text { Project } \\
\text { Planner }\end{array}$ & $\begin{array}{l}\text { Primavera Systems, } \\
\text { Inc. (USA); distrib- } \\
\text { utor in Russia - } \\
\text { PMSOFT company } \\
\text { (http://www.pmsoft } \\
\text {.ru) }\end{array}$ & $\begin{array}{l}\text { http://www.pr } \\
\text { imavera.com }\end{array}$ & $\begin{array}{l}\text { It is used in calendar-network planning and management, } \\
\text { taking into account the needs for material, labor and fi- } \\
\text { nancial resources of medium and large-scale projects in } \\
\text { various industries, although this product has the widest } \\
\text { distribution in the field of management of construction } \\
\text { and engineering projects }\end{array}$ \\
\hline $\begin{array}{l}\text { SureTrak } \\
\text { Project } \\
\text { Manager }\end{array}$ & $\begin{array}{l}\text { Primavera Systems, } \\
\text { Inc. (USA); distrib- } \\
\text { utor in Ukraine - } \\
\text { PMSOFT company } \\
\text { (http://www.pmsoft } \\
\text {.ru) }\end{array}$ & $\begin{array}{l}\text { http://www.pr } \\
\text { imavera.com }\end{array}$ & $\begin{array}{l}\text { SureTrak is a simplified project management system for } \\
\text { Primavera Systems. This fully Russified product is aimed } \\
\text { at monitoring the implementation of small projects and / } \\
\text { or parts of large projects. Can work independently or in } \\
\text { conjunction with Primavera Project Planner in the corpo- } \\
\text { rate project management system }\end{array}$ \\
\hline Spider Project & $\begin{array}{l}\text { Spider Technolo- } \\
\text { gies Group } \\
\text { (Russia) }\end{array}$ & project.ru & $\begin{array}{l}\text { The system is designed taking into account the needs, fea- } \\
\text { tures and priorities of the Russian market. It is character- } \\
\text { ized by powerful algorithms for the distribution of limited } \\
\text { resources and a large number of additional functions. Spi- } \\
\text { der Project comes in two versions - Professional and } \\
\text { Desktop. The Spider Project package can be used as a free } \\
\text { licensed version, designed for } 40 \text { operations }\end{array}$ \\
\hline Project Expert & $\begin{array}{l}\text { Pro-Invest Consult- } \\
\text { ing (Russia) }\end{array}$ & $\begin{array}{c}\text { http://www.pr } \\
\text { o-invest.com }\end{array}$ & $\begin{array}{l}\text { It provides construction of a financial model of the enter- } \\
\text { prise, analysis of the financial efficiency of business pro- } \\
\text { jects, development of a strategic development plan and } \\
\text { preparation of a business plan. The system is recommend- } \\
\text { ed for use by state structures of federal and regional level, } \\
\text { as a standard tool for developing enterprise development } \\
\text { plans }\end{array}$ \\
\hline $\begin{array}{l}\text { 1С-Рарус: } \\
\text { Управление } \\
\text { проектами }\end{array}$ & 1C-Rarus (Russia) & http://rarus.ru & $\begin{array}{l}\text { Russian development on the platform of the accounting } \\
\text { system „1C: Enterprise" version 8.0. It is intended for } \\
\text { planning, organization, coordination and control of design } \\
\text { works and resources. The standard solution is developed } \\
\text { only by the means and methods of the "1C: Enterprise” } \\
\text { program and is an application of the „Accounting” com- } \\
\text { ponent of the „1C: Enterprise" program version 8.0. Pro- } \\
\text { ject management is integrated with any configurations that } \\
\text { use component } 1 \mathrm{C}, \text {,Accounting” }\end{array}$ \\
\hline
\end{tabular}


ГАЛУЗЕВИЙ АСПЕКТ РОЗВИТКУ НАЦІОНАЛЬНОГО ГОСПОДАРСТВА

Table 2

Initial data, taking into account technological and engineering features in the sequence of execution of interrelated works and duration norms for the construction of heating networks

\begin{tabular}{|c|c|c|}
\hline Designation and specification of work & $\begin{array}{l}\text { Immediately } \\
\text { previous work }\end{array}$ & $\begin{array}{l}\text { Duration of } \\
\text { works, days }\end{array}$ \\
\hline S Preparatory operations (preparation for engineering works) & - & 10 \\
\hline $\mathbf{Z}$ Preparation of the network area for disconnection (informing the consumers) & - & 30 \\
\hline A Planning and designing works & $\mathrm{S}$ & 2 \\
\hline B Arrangement of a list of materials & A & 1 \\
\hline C Purchase of pipes & $\mathrm{B}$ & 30 \\
\hline $\begin{array}{l}\text { F Purchase of flanges, shut-off valves and other materials and stuff for in- } \\
\text { stallation works }\end{array}$ & $\mathrm{B}$ & 45 \\
\hline G Manufacture of sections & $\mathrm{C}$ & 5 \\
\hline I Disconnection of the network area & $\mathrm{Z}, \mathrm{B}$ & 1 \\
\hline $\begin{array}{l}\text { K Digging of the canal or erection of the supports (depending on the meth- } \\
\text { od of laying) }\end{array}$ & $\mathrm{B}$ & 2 \\
\hline O Dismantle of the old pipeline & $\mathrm{I}, \mathrm{K}$ & 6 \\
\hline P Installation of a new pipeline & $\mathrm{O}, \mathrm{G}$ & 6 \\
\hline Q Welding works & $\mathrm{P}$ & 2 \\
\hline R Installation of flanges and other details & $\mathrm{F}, \mathrm{I}, \mathrm{K}$ & 1 \\
\hline T Fitting of the pipeline and other details & $\mathrm{R}, \mathrm{Q}$ & 1 \\
\hline U Leak testing of the pipeline & $\mathrm{T}$ & 1 \\
\hline W Insulation & $\mathrm{R}, \mathrm{Q}$ & 4 \\
\hline $\mathbf{X}$ Land management works & $\mathrm{T}, \mathrm{W}$ & 1 \\
\hline Y Cleaning of the area & $\mathrm{U}, \mathrm{X}$ & 1 \\
\hline
\end{tabular}

Source: $[11 ; 12]$.

Table 3

Variation in timing for execution of works on upgrading and improvement of heating networks and indicators of time reserves, days

\begin{tabular}{|c|c|c|c|c|c|c|c|c|c|}
\hline \multirow{2}{*}{ Work (i) } & \multirow{2}{*}{ Duration } & \multicolumn{2}{|c|}{$\begin{array}{c}\text { The earliest possible } \\
\text { term }\end{array}$} & $\begin{array}{c}\text { The most recent } \\
\text { deadline }\end{array}$ & \multicolumn{4}{c|}{ Time reserves } \\
\cline { 3 - 10 } & & $\begin{array}{c}\text { beginning } \\
\left(\mathrm{ES}_{\mathrm{i}}\right)\end{array}$ & $\begin{array}{c}\text { ending } \\
\left(\mathrm{EF}_{\mathrm{i}}\right)\end{array}$ & $\begin{array}{c}\text { beginning } \\
\left(\mathrm{LS}_{\mathrm{i}}\right)\end{array}$ & $\begin{array}{c}\text { ending } \\
\left(\mathrm{LF}_{\mathrm{i}}\right)\end{array}$ & $\begin{array}{c}\text { total } \\
\left(\mathrm{TF}_{\mathrm{i}}\right)\end{array}$ & $\begin{array}{c}\text { free } \\
\left(\mathrm{FF}_{\mathrm{i}}\right)\end{array}$ & $\begin{array}{c}\text { independent } \\
\left(\mathrm{IF}_{\mathrm{i}}\right)\end{array}$ & $\begin{array}{c}\text { secured } \\
\left(\mathrm{SF}_{\mathrm{i}}\right)\end{array}$ \\
\hline $\begin{array}{c}\text { Beginning of } \\
\text { the project }\end{array}$ & 0 & 0 & 0 & 0 & 0 & - & - & - & - \\
\hline $\mathrm{S}$ & 10 & 0 & 10 & 0 & 10 & 0 & 0 & 0 & 0 \\
\hline $\mathrm{Z}$ & 30 & 0 & 30 & 14 & 44 & 14 & 0 & 0 & 14 \\
\hline $\mathrm{A}$ & 2 & 10 & 12 & 10 & 12 & 0 & 0 & 0 & 0 \\
\hline $\mathrm{B}$ & 1 & 12 & 13 & 12 & 13 & 0 & 0 & 0 & 0 \\
\hline $\mathrm{C}$ & 30 & 13 & 43 & 16 & 46 & 3 & 0 & 0 & 3 \\
\hline $\mathrm{F}$ & 45 & 13 & 58 & 13 & 58 & 0 & 0 & 0 & 0 \\
\hline $\mathrm{G}$ & 5 & 43 & 48 & 46 & 51 & 3 & 0 & 0 & 0 \\
\hline $\mathrm{I}$ & 1 & 30 & 31 & 44 & 45 & 14 & 0 & 0 & 0 \\
\hline $\mathrm{K}$ & 2 & 13 & 15 & 43 & 45 & 30 & 1 & 16 & 30 \\
\hline $\mathrm{O}$ & 6 & 31 & 37 & 45 & 57 & 14 & 11 & 0 & 0 \\
\hline $\mathrm{P}$ & 6 & 48 & 54 & 51 & 57 & 3 & 0 & 0 & 0 \\
\hline $\mathrm{Q}$ & 2 & 54 & 56 & 57 & 59 & 3 & 3 & 0 & 0 \\
\hline $\mathrm{R}$ & 1 & 58 & 59 & 58 & 59 & 0 & 0 & 0 & 0 \\
\hline $\mathrm{T}$ & 1 & 59 & 60 & 62 & 63 & 3 & 0 & 0 & 3 \\
\hline $\mathrm{U}$ & 1 & 60 & 61 & 63 & 64 & 3 & 3 & 0 & 0 \\
\hline $\mathrm{W}$ & 4 & 59 & 63 & 59 & 63 & 0 & 0 & 0 & 0 \\
\hline $\mathrm{X}$ & 1 & 63 & 64 & 63 & 64 & 0 & 0 & 0 & 0 \\
\hline $\mathrm{Y}$ & 1 & 64 & 65 & 64 & 65 & 0 & 0 & 0 & 0 \\
\hline Ending of the & 0 & 65 & 65 & 65 & 65 & - & - & - & - \\
\hline project & 0 & & & & & & & 0 \\
\hline
\end{tabular}

${ }^{1}$ In order to minimize the time needed for the disconnection of heat supply system for consumers, the overnight works are expected. 
ГАЛУЗЕВИЙ АСПЕКТ РОЗВИТКУ НАЦІОНАЛЬНОГО ГОСПОДАРСТВА

Taking into account the methodological principles of creation, calculation of parameters and optimization of network diagrams, disclosed, as an example, in [13, p. 172-202], the ,nodework" network model for the given statement of problem can be represented as follows (Figure).

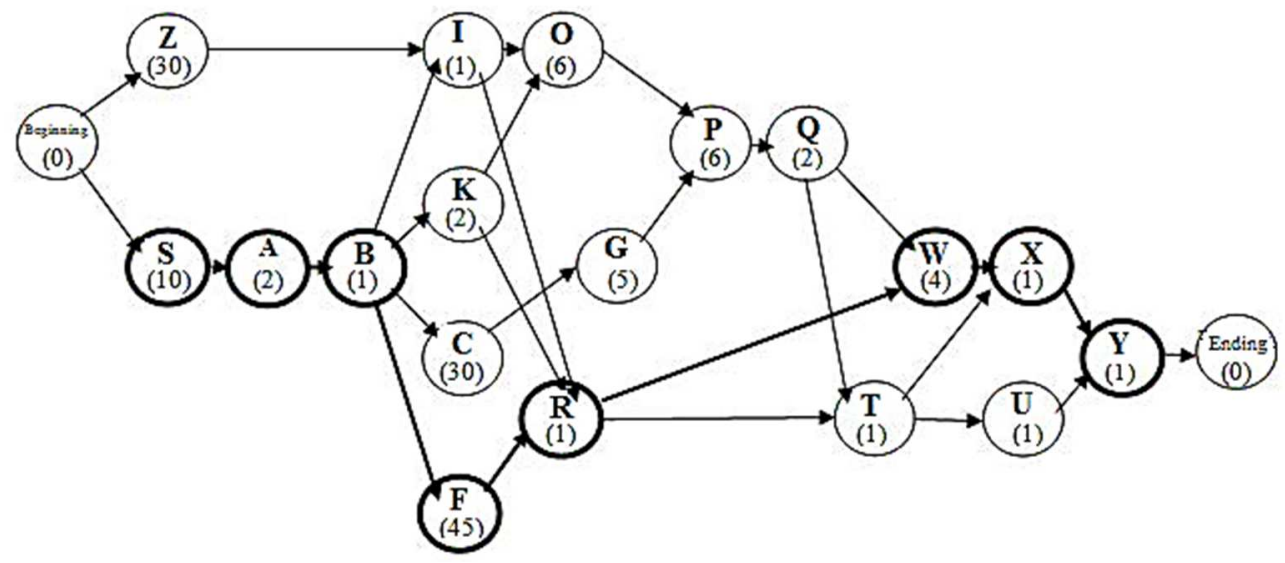

Figure. Network model of the project ${ }^{2}$

The total time reserve of works S, A, B, F, R, W, X, Y is equal to zero, indicating the creation of a critical path by these works precisely, and also a necessity to carefully monitor the timing of their execution. The work $\mathrm{G}$, although it has a total time reserve (3 days), has no free reserves, because its delay will lead to untimely execution of the work P. The work $\mathrm{O}$ has a total time reserve of 14 days, but its free time reserve is only 11 days and any delay beyond 11 days will result in violation of terms for the earliest possible start of the work P. Only the work $\mathrm{K}$ has a non-zero independent reserve of time, while the rest of works can completely lose their time reserve due to untimely execution of previous works. Works $\mathrm{Z}, \mathrm{C}, \mathrm{K}$ and $\mathrm{T}$ are characterized by a non-zero secured time reserve. The following Figure shows that delay of the work $\mathrm{C}$ can occur due to the untimely execution of works $\mathrm{G}$ and $\mathrm{P}$, and work $\mathrm{K}$ may be delayed as a result of delay of the work $\mathrm{O}$. Works $\mathrm{O}, \mathrm{G}$ and $\mathrm{P}$ will be deprived of secured time reserve due to possible delays in previous works.

Conclusions. One of the key messages of the 5th Vienna Energy Forum, organized by the United Nations Organization on Industrial Development, UNIDO, the International Institute for Applied Systems Analysis (IIASA), the Austrian government and the initiative Sustainable Energy for All (SEforALL), which in May 2017 gathered more than 1650 participants out of 128 countries, provides for energy as the most important component for the implementation of the Agenda until 2030 and the Paris Climate Agreement, and to meet the needs of the relative energy security [14]. The energy intensity of Ukraine's GDP exceeds that of the UK by 4.8 times, Turkey by 3.8 times, Poland by 3.0 times [15, p. 109], which does not contribute to increasing the competitiveness of our state to the level of the leading countries of Europe, ensuring the continuous and stable operation of the energy complex of Ukraine.

The proposed approach can be used by state authorities, business entities and investment companies in the process of development of measures to increase the energy efficiency rate at the macro-, meso- and microeconomic levels, which will involve intensification of innovation activities, more complete implementation of social and economic potential of business entities and local communities.

Management of the process of upgrading boiler stations and heating networks through the application of network methods, in particular, determination of admissible delays as a time reserve for further coordination of project implementation, will help managers to establish the

${ }^{2}$ In this case the final work with the execution of 0 days could not be entered, since the last work regarding the Cleaning of the area (F) and the display of conditional work „Ending” are both carried out specifically by the procedure of model constructing, in order to obtain solely initial and final nodes. 
ГАЛУЗЕВИЙ АСПЕКТ РОЗВИТКУ НАЦІОНАЛЬНОГО ГОСПОДАРСТВА

sequence and timing as for the use of limited resources throughout the entire period of project implementation, to conduct dynamic regulation of timing for the beginning of each work, to optimize rational allocation of project funds and materials due to the criterion of reducing duration of the whole project, to perform an analysis of trade-off relationships between the costs and timing of various works, with regard to the available time reserve.

\section{References}

1. Prohrama diialnosti Kabinetu Ministriv Ukrainy [Program of activity of the Cabinet of Ministers of Ukraine]. № 1099-VIII (on April 14, 2016). Retrieved from https://zakon.rada.gov.ua/laws/show/1099-19?lang=en.

2. Pro skhvalennya kontseptsiyi Enerhetychnoyi stratehii Ukrainy na period do 2035 r. «Bezpeka, enerhoefektyvnist, konkurentospromozhnist» [On approval of the concept of the Energy Strategy of Ukraine for the period up to 2035. «Security, Energy Efficiency, Competitiveness»]. № 605-p (dated August 18, 2017). Retrieved from https://zakon.rada.gov.ua/laws/show/605-2017-\%D1\%80.

3. Lazanovskyi, P. P. (2016). Vykorystannia metodu merezhevoho planuvannia v operatsiinomu upravlinni vyrobnytstvom knyzhkovo-zhurnalnoi produktsiyi [The use of network planning in the operational management of the production of book-magazine products]. Naukovi zapysky. Ekonomichni nauky - Scientific notes. Economic Sciences, 2 (53), 205-212 [in Ukrainian].

4. Sybal, Ya., Ivanytskyi, I. \& Kadyuk, Z. (2014). Sitkovi metody planuvannya ta upravlinnya v optymizatsiyi vyrobnytstva produktsiyi [Network methods of planning and management in production optimization]. Visnyk L'vivs'koho natsional'noho ahrarnoho universytetu. Seriia: Ekonomika APK Visnyk of Lviv National Agrarian University. Series: Economy of agroindustrial complex, 21 (1), 322326. Retrieved from http://nbuv.gov.ua/UJRN/Vlnau_econ_2014_21\%281\%29_61.

5. Sokhan, V. V. (2015). Sitovi modeli operatyvnoho upravlinnia proektamy v dorozhnomu budivnytstvi [Network models of operational management of projects in road construction]. Visnyk Natsionalnoho transportnoho universytetu - The National Transport University Bulletin, 31, 499-507. Retrieved from http://publications.ntu.edu.ua/visnyk/31_1_tech_2015/499-507.pdf.

6. Timinskyi, O. H. (2008). Alhorytm pobudovy kalendarno-sitovoyi modeli proektu z elementamy proaktyvnosti [Algorithm for constructing a calendar network model of the project with elements of proactivity]. Upravlinnya proektamy ta rozvytok vyrobnytstva - Project management and production development, 4 (28), 31-36 [in Ukrainian].

7. Ekonomiko-matematychne modelyuvannya: zb. mat. Pershoyi nats. nauk.-metod. konf. [Economic-mathematical modeling: a collection of materials of the First National Scientific and Methodological Conference] (September 30 - October 1, 2016). Kyiv: KNEU [in Ukrainian].

8. Fyllyps, D. \& Harsia-Dyas, A. (1984). Metody analiza setei [Network Analysis Methods] (Kovalenko, E. H. \& Furuhyana, M. H., trans; B. Sushkova, ed.). Moscow: Mir [in Russian].

9. Yushchenko, N. L. (2016). Matematychni modeli vyznachennya rezervu chasu dlya zbalansovanoho rozpodilu trudovykh, material'nykh i finansovykh resursiv pry modernizatsiyi komunal'noyi teploenerhetyky Ukrayiny [Mathematical models to determine the reserve time a balanced distribution of manpower, material and financial resources for modernization of municipal power system of Ukraine]. Naukovyi visnyk Polissia - Scientific Bulletin of Polissia, 2 (6), 16-25 [in Ukrainian].

10. Yushchenko, N. L. (2017). Informatsioni tekhnolohii, shcho realizovuyut modeli ta metody analizu v protsesi pryynyattya rishen' shchodo resursiv i vytrat pry modernizatsiyi teploenerhetyky $\mathrm{v}$ Ukrayini [Information technologies implementing models and methods of analysis in the decision making process concerning resources and costs during the modernization of heat and power engineering in Ukraine]. Matematychne ta imitatsiyne modelyuvannia system. MODS 2017: tezy dopovidei Dvanadtsiatoi mizhnarodnoi nauk.-prakt. konf. - Mathematical and simulation modeling of systems. MODIS'2017: theses of the reports of the Twelfth International Science Pract. Conf. (Chernihiv, June 26-29, 2017) (pp. 224-232). Chernihiv: ChNTU (in Ukrainian).

11. Zakharenko, S. E. (Ed.), Zakharenko, Yu. S., Nykolskyi, I. S. \& Pishchikov, M. A. (1984). Spravochnik stroitelia teplovykh setei [Directory of thermal network builder]. Moscow: Enerhoatomyzdat [in Russian].

12. Kulakov, N. H. \& Berezhnov, I. A. (1977). Spravochnik po ekspluatatsii sistem teplosnabzheniia [Handbook on the operation of heat supply systems]. Kyiv: Budivelnik [in Russian]. 
ГАЛУЗЕВИЙ АСПЕКТ РОЗВИТКУ НАЦІОНАЛЬНОГО ГОСПОДАРСТВА

13. Sakovych, V. A. (1984). Issledovanie operatsii (determinirovannye metody i modeli) [Operations Research (deterministic methods and models)]. Minsk: Vysheishaia shkola [in Russian].

14. Site of the UNIDO. Retrieved from http://www.unido.org/news/press/vienna-energy-forum-1.html.

15. Tsili rozvytku tysyacholittia Ukraina: 2000-2015. Natsionalna dopovid [Millennium Development Goals Ukraine: 2000-2015. National report]. Retrieved from http://un.org.ua/images/ stories/docs/2015_MDGs_Ukraine_Report_ukr.pdf.

\section{References (in language original)}

1. Про Програму діяльності Кабінету Міністрів України: Постанова Верховної Ради України; Програма від 14.04.2016 № 1099-VIII. URL : https://zakon.rada.gov.ua/laws/show/1099-19?lang=en.

2. Про схвалення концепції Енергетичної стратегії України на період до 2035 р. "Безпека, енергоефективність, конкурентоспроможність": Проект Розпорядження Кабінету міністрів України від 18.08.2017 № 605-p. URL: https://zakon.rada.gov.ua/laws/show/605-2017-\%D1\%80.

3. Лазановський П. П. Використання методу мережевого планування в операційному управлінні виробництвом книжково-журнальної продукції. Наукові записки. Економічні науки. 2016. № 2(53). C. 205-212.

4. Сибаль Я., Іваницький І., Кадюк 3. Сіткові методи планування та управління в оптимізації виробництва продукції. Вісник Львівського наиіонального аграрного університету. Серія: Економіка АПК. 2014. № 21 (1). C. 322-326. URL: http://nbuv.gov.ua/UJRN/ Vlnau_econ_2014_21\%281\%29_61.

5. Сохань В. В. Сітьові моделі оперативного управління проектами в дорожньому будівництві. Вісник Начіонального транспортного університету. 2015. № 31. C. 499-507. URL: http://publications.ntu.edu.ua/visnyk/31_1_tech_2015/499-507.pdf.

6. Тімінський О. Г. Алгоритм побудови календарно-сітьової моделі проекту з елементами проактивності. Управління проектами та розвиток виробниитва: зб. наук. пр. 2008. № 4 (28). C. $31-36$.

7. Економіко-математичне моделювання: зб. мат. Першої нац. наук.-метод. конф. (30 вересня - 1 жовтня 2016 р., м. Київ). Київ: КНЕУ, 2016. 405 с.

8. Филлипс Д., Гарсиа-Диас А. Методы анализа сетей / пер. с англ. Е. Г. Коваленко, М. Г. Фуругяна; под ред. Б. Г. Сушкова. Москва: Мир, 1984. 496 с.

9. Ющенко Н. Л. Математичні моделі визначення резерву часу для збалансованого розподілу трудових, матеріальних і фінансових ресурсів при модернізації комунальної теплоенергетики України. Науковий вісник Полісся. 2016. № 2. С. 16-25.

10. Ющенко Н. Л. Інформаційні технології, що реалізовують моделі та методи аналізу в процесі прийняття рішень щодо ресурсів і витрат при модернізації теплоенергетики в Україні. $M a-$ тематичне та імітаиійне моделювання систем. МОДС'2017: тези доповідей Дванадцятої міжнародної наук.-практ. конф. (Чернігів, 26-29 червня 2017 р.). Чернігів: ЧНТУ, 2017. С. 224-232.

11. Справочник строителя тепловых сетей / под общ. ред. С. Е. Захаренко. Москва: Энергоатомиздат, 1984. $184 \mathrm{c}$.

12. Кулаков Н. Г., Бережнов И. А. Справочник по эксплуатации систем теплоснабжения. Киев: Будівельник, 1977. 352 с.

13. Сакович В. А. Исследование операций (детерминированные методы и модели): Справочное пособие. Минск: Выш. шк., 1984. 256 с.

14. United Nations Industrial Development Organization. URL: http://www.unido.org/news/ press/vienna-energy-forum-1.html.

15. Цілі розвитку тисячоліття Україна: 2000-2015. Національна доповідь. Київ, 2015. 125 с. URL: http://un.org.ua/images/stories/docs/2015_MDGs_Ukraine_Report_ukr.pdf.

Yushchenko Nadiia - PhD in Economics, Associate Professor, Associate Professor of Department of Accounting,

Taxation and Audit, Chernihiv National University of Technology (95 Shevchenka Str., 14035 Chernihiv, Ukraine).

Ющенко Надія Леонідівна - кандидат економічних наук, доцент, доцент кафедри бухгалтерського обліку,

оподаткування та аудиту, Чернігівський національний технологічний університет (вул. Шевченка, 95,

м. Чернігів, 14035, Україна).

Ющенко Надежда Леонидовна - кандидат экономических наук, доцент, доцент кафедры бухгалтерского

учета, налогообложения и аудита, Черниговский национальный технологический университет (ул. Шевчен-

ко, 95, г. Чернигов, 14035, Украина). 
ГАЛУЗЕВИЙ АСПЕКТ РОЗВИТКУ НАЦІОНАЛЬНОГО ГОСПОДАРСТВА

E-mail: yushchenkonadezhda@gmail.com

ORCID: http://orcid.org/0000-0001-5213-8341

Researcher ID: F-3202-2016

Petrakov Yaroslav - PhD in Economics, Associate Professor, Director General of the Directorate of Strategic Planning and European Integration, Ministry of Culture of Ukraine (19 Ivan Franko Str., 01601 Kyiv, Ukraine).

Петраков Ярослав Валерійович - кандидат економічних наук, доцент, генеральний директор Директорату стратегічного планування та європейської інтеграції Міністерства культури України (вул. Івана Франка, 19, м. Київ, 01601).

Петраков Ярослав Валериевич - кандидат экономических наук, доцент, генеральный директор Директората стратегического планирования и европейской интеграции Министерства культуры Украины (ул. Ивана Франка, 19, г. Киев, 01601).

Hnedina Kateryna - PhD in Economics, Associate Professor, Associate Professor of Department of Accounting, Taxation and Audit, Chernihiv National University of Technology (95 Shevchenka Str., 14035 Chernihiv, Ukraine).

Гнедіна Катерина Володимирівна - кандидат економічних наук, доцент, доцент кафедри бухгалтерського обліку, оподаткування та аудиту Чернігівського національного технологічного університету (вул. Шевченка, 95, м. Чернігів, 14035, Україна).

Гнедина Екатерина Владимировна - кандидат экономических наук, доцент, доцент кафедры бухгалтерского учёта, налогообложения и аудита Черниговского национального технологического университета (ул. Шевченко, 95, г. Чернигов, 14035, Украина).

E-mail: gkv2015oa@gmail.com

ORCID: http://orcid.org/0000-0001-9471-0932

Researcher ID: F-1707-2014 